\title{
The Labour Rights Agenda in Free Trade Agreements
}

\author{
James Harrison \\ University of Warwick, United Kingdom \\ j.harrison.3@warwick.ac.uk
}

\begin{abstract}
This article explores the implications of the proliferation of labour provisions in free trade agreements (FTAs) in recent years. It reviews a relatively new form of empirical scholarship on the effectiveness of US and EU labour provisions. In doing so, it helps to identify a large gap between, on the one hand, the rhetoric of policymakers on the importance of such provisions and, on the other, the reality of what they achieve in practice. Reform efforts on both sides of the Atlantic are then examined to find that these also contain major deficiencies. The article therefore asks whether the ineffectiveness of the labour rights agenda in FTAs should be seen as part of a burgeoning class critique of trade policy. In the current political climate, it also suggests that the deficiencies identified, and how they should be resolved, require far greater engagement from both mainstream academia and trade policy communities.
\end{abstract}

\section{Keywords}

core labour standards - European Union - labour rights - sustainable development United States of America

* Professor, University of Warwick, School of Law (Coventry, United Kingdom). This article arises in part from research undertaken by Mirela Barbu, Liam Campling, James Harrison, Ben Richardson, and Adrian Smith as part of a ESRC-funded project entitled 'Working Beyond the Border: European Union Trade Agreements and International Labour Standards' (ES/Moo9343/1). The author is very grateful to the editors of this Special Issue, Caroline Henckels and Markus Wagner, as well as to the anonymous reviewers, for their insightful comments on earlier drafts. 
One telling of the trade and labour 'linkage' story has it following a similar trajectory to other recent trade and investment law issues discussed in this Special Issue. Deadlock at the World Trade Organization (WTO) has been followed by an upsurge in the prevalence of labour provisions within free trade agreements (FTAs). Viewed from this perspective, the story of trade and labour appears to be a triumph for the agendas of developed countries, who have long championed the inclusion of labour provisions, over developing countries, who fought for their exclusion. But there is also another story unfolding which a relatively new form of empirical scholarship across the social sciences has helped to tell: the failures and deficiencies of labour provisions in relation to exactly those workers' rights they are supposed to protect and promote.

In this article, it will be argued that it is the failures that are more significant, and that these failures raise questions of critical importance for trade policymaking in the future. Policymakers have used the presence of 'strong' labour provisions in trade agreements to argue that the social consequences of trade commitments are taken seriously. How are they now responding, and how should they respond in the future, to the serious deficiencies in those provisions which are becoming apparent? At the same time, is the ineffectiveness of labour provisions becoming part of a burgeoning class critique of trade policy? And do these issues require greater engagement from mainstream academic and trade policy communities?

The article starts by recalling the history of the trade and labour linkage, and how it has played out within the WTO and in the trade agendas of the major proponents for their inclusion within trade agreements. It explores how, since the deadlock at the WTO, the number of trade agreements that include labour provisions have expanded greatly (Section 2). Thereafter, it focuses on two leading proponents of labour provisions in trade agreements, the United States and the European Union (EU), explains how their models function, and identifies key limitations and failings (Sections 3 and 4). Then, the recent efforts that have been made to strengthen labour provisions on both sides of the Atlantic are examined (Section 5 ). The results of these reform efforts are scrutinised, with concern raised about their limited ambition. In conclusion, it is argued that a paradigm shift is needed to spur engagement of academic and trade policy communities with the labour rights agenda (Section 6). 
There is a long history of legislating on labour rights and international trade that started well before the advent of the multilateral trade regime. From the 1890 s onwards, various national laws and international treaties prohibited, inter alia, the import of slaves and goods produced by prison labour. ${ }^{1}$ The prohibition on goods made by prisoners found its way into the general exception clause of the General Agreement on Trade and Tariffs (GATT) under Article XX(e). Otherwise, efforts to include labour rights within the multilateral trading system remained unsuccessful. Since its inception in the mid-twentieth century, there were periodic attempts to have labour conditionality, often as part of a wider social clause, included within the GATT and subsequently the WTO. This was generally the result of proposals put forward by the United States and supported by various other developed countries, including EU Member States. Whereas such endeavours date back to the 195 os, their prominence reached new heights in the run-up to the 1996 WTO Ministerial Conference in Singapore, where they became a major stumbling block for the trade negotiations. ${ }^{2}$ The Singapore Declaration ${ }^{3}$ resulting from that meeting clarified that the International Labour Organization (ILO) was the proper forum to address labour rights issues, and that the WTO should not be taking on a role with regard to enforceable standards that would allow States to impose trade restrictions. ${ }^{4}$ The rationale behind this approach was that many developing countries were concerned that a failure to adhere to labour rights contained in trade agreements would allow developed trade partners to retaliate through the WTO's relatively powerful dispute settlement mechanism. ${ }^{5}$ Labour issues also became a major issue leading up to the WTO Seattle Ministerial Conference of 1999. The breakdown of the conference was, to a certain extent, due to proposals for enforceable labour standards within

1 Steve Charnovitz, "The Influence of International Labour Standards on the World Trading Regime - A Historical Overview' (1987) 126 Intl Lab Rev 565.

2 Virginia A Leary, 'The WTO and the Social Clause: Post-Singapore' (1997) 1 EJIL 118, 119. Leary reports that at the Conference, an invitation to the ILO to speak was withdrawn due to objections from developing countries as to the discussion of labour issues at the meeting.

3 Singapore Ministerial Declaration (13 December 1996) WT/MIN(96)/DEC/W, para 4.

4 For a more detailed description of the process leading up to the Singapore Declaration and its aftermath, including the United States' reaction, see Steve Charnovitz (ed), Trade Law and Global Governance (Cameron May 2002) 258.

5 See James Harrison, The Human Rights Impact of the World Trade Organisation (Hart Publishing 2007) $\mathrm{ch} 5$ for a more detailed exposition of these events. 
the WTO framework: US President Bill Clinton publicly stated that a proposed working group, established to look into issues of trade and labour linkage, should define a set of core labour standards that would then be incorporated as enforceable provisions into all WTO agreements. This united developing countries in opposition and, in the words of one commentator, 'sealed the fate of the Seattle conference. ${ }^{6}$ At the following WTO Ministerial Conference in Doha, WTO members reaffirmed that the ILO was the competent body to set and deal with labour standards. ${ }^{7}$

Since the Doha Ministerial Conference, there have been no serious attempts to include labour provisions into multilateral trade agreements. ${ }^{8}$ However, they have had a resurgence in the bilateral and regional setting. ${ }^{9}$ The number of FTAs negotiated in recent years that include labour provisions has expanded enormously. While there were only three trade agreements with labour provisions in 1995, this increased to 77 by 2016, elevating the overall share of trade agreements with labour provisions from 7.3 per cent in 1995 to 28.8 per cent in $2016 .{ }^{10}$ Fuelling this surge are a number of countries that had been pushing for labour inclusion at the WTO. The EU and the United States, alongside Canada, have been particularly active in concluding trade agreements that incorporate labour standards in recent years. But they are not alone, and the presence of labour provisions in trade agreements is increasingly becoming a global phenomenon. As of 2016, 136 countries had at least one trade agreement that included labour provisions. ${ }^{11}$

It is therefore possible to tell a story that is familiar in many other areas of international trade law. On a range of issues, from stronger forms of intellectual property protection, to enhanced protection for investors, developed countries have seen their negotiating agendas blocked in the WTO, but have managed to be far more successful in the bilateral or preferential setting.

6 Aravind Panagaryia, 'Trade-Labour Link: A Post-Seattle Analysis' in Zdenek Drabek (ed), Globalisation under Threat: The Stability of Trade Policy and Multilateral Agreements (Edward Elgar 2001) 102, 288.

$7 \quad$ Kofi Addo, 'The Correlation Between Labour Standards and International Trade - Which Way Forward?' (2002) 36 JWT 285.

8 Jan Orbie, 'Promoting Labour Standards Through Trade: Normative Power or Regulatory State Europe' in Richard G Whitman (ed), Normative Power Europe: Empirical and Theoretical Perspectives (Palgrave MacMillan 2011) 161.

9 Beyond the scope of this article, both the US and the EU had begun to link their unilateral trade preferences (known as Generalised System of Preferences or GSP) to minimum labour standards from the 1980 on onwards. See Brian Burgoon, "The Rise and Stall of Labor Linkage in Globalization Politics' (2004) 41 Intl Pol 196. International Labour Organisation, Handbook on Assessment of Labour Provisions in Trade and Investment Agreements (ILO 2017) 11 (ILO Handbook). ibid 13. Although it should be noted that there are marked regional differences. 
The negotiating dynamics of bilateral and regional agreements have been more conducive to the fulfilment of agendas that were toxic in the multilateral setting. There is less focused media and civil society attention, and more powerful countries are able to push their agendas more successfully when less powerful countries cannot group together in large blocs, as is the case at the WTO ${ }^{2}$ Viewed through this lens, the trade and labour story looks like a victory for developed countries over the interests of developing countries. Scholars in the 1990s predicted that this victory could lead to the unjustified exclusion of developing country goods from developed country markets. ${ }^{13}$ Have those fears now become a reality?

There is evidence to suggest a more nuanced picture. There has been no suggestion that any of the labour provisions that have come into force have led to disguised protectionism in practice. At the same time, the labour agenda in trade agreements is no longer something only pushed by developed countries. A quarter of all trade agreements with labour provisions are now between developing country trading partners (i.e. do not include developed countries), including many States in Latin America and Sub-Saharan Africa. ${ }^{14}$ Does this imply that at least some developing countries have abandoned their opposition to a trade-labour linkage at the WTO and would sign up to such provisions even in the absence of pressure from their developed counterparts? Or have the labour provisions themselves changed so that they are no longer feared? In order to obtain a more fine-grained understanding, one needs to investigate the substance of the labour provisions that have been negotiated, what they have sought to achieve, and the effects that such provisions have had among trade partners and the wider global economy. It is only then that one can assess whether meaningful labour provisions have become a widely accepted part of trade agreements around the world.

While labour provisions within trade agreements are now plentiful across the globe, the United States and the EU remain the most high-profile proponents of linkage, their models of protection are regularly contrasted within the academic literature, and those models have been followed, to varying degrees, by other countries. In the following two sections, these two models are explained and critically evaluated.

Our ability to tell this critical story is fuelled by a relatively new form of empirical study which is still rare in relation to any form of legal scholarship on

\footnotetext{
12 On intellectual property and access to medicines, see eg Susan Sell, 'TRIPS-Plus Free Trade Agreements and Access to Medicines' (2007) 28 Liverpool L Rev 41.

13 For a review of early trade-labour linkage debates, see Lance Compa and Stephen Diamond (eds), Human Rights, Labor Rights and Trade (U Penn Press 1996).

14 See ILO Handbook (n 10).
} 
international trade law obligations. ${ }^{15}$ In the narrower field of academic study of the trade-labour linkage, either the text of labour provisions or jurisprudence of dispute settlement have been the traditional focus. ${ }^{16}$ More recently, however, scholars have sought to investigate, through qualitative empirical study, how labour provisions have been implemented via the institutional frameworks created by the trade agreements, as well as by government officials of the treaty parties. ${ }^{17}$ Viewed from this perspective, the unfolding controversy over labour provisions relates to their failure to significantly impact those workers' rights they are supposed to protect and promote. This stands distinct from controversies on other issues where deadlock at the WTO eventually led to inclusion of commitments in FTAs. Most significantly, intellectual property and investor protection provisions in trade agreements have been contentious due to their potential to impose restrictions on governments' regulatory autonomy and, thereby, offer valuable protection to investors and intellectual property holders. ${ }^{18}$ This raises questions about whether the failures and limitations of provisions designed to protect the rights of workers, explored in greater detail below, need to be viewed alongside the relative success of provisions designed to protect the interests of capital (investors and intellectual property holders).

The EU's trade agreements have consistently contained provisions on labour standards since 1999, when it concluded its agreement with South Africa. ${ }^{19}$

15 For instance, there are no articles in the Journal of World Investment and Trade, Journal of International Economic Law or Journal of World Trade over the last 3 years (2016-2018) which conduct empirical investigations of the impact of trade or investment law obligations. Linda J Allen, 'Reassessing the "Green" in NAFTA' (2018) 52 JWT 557 contains extensive references to empirical work elsewhere on the impacts of NAFTA to support the arguments made in the article, but does not itself present detailed empirical research findings.

16 See eg Kofi Addo, Core Labour Standards and International Trade (Springer 2015). As will be discussed below, such cases are a rare occurrence in relation to most trade agreements.

17 This literature is extensively discussed in Sections 3 and 4 below.

18 For a summary of key arguments in relation to the significant impacts of international investment protection, see Emma Aisbett and others, Rethinking International Investment Governance: Principles for the 21st Century (Columbia Center on Sustainable Investment 2018) chs 6-8. Charting many of the significant impacts of intellectual property protection in EU trade agreements, Josef Drexl, Henning Grosse Ruse-Khan and Souheir Nadde-Phlix (eds), EU Bilateral Trade Agreements and Intellectual Property: For Better or Worse? (Springer 2014).

19 Agreement on Trade, Development and Cooperation Between the European Community and its Member States, of the One Part, and the Republic of South Africa, of the Other Part [1999] OJ L311/3. 
Its approach has gradually evolved over time and formalised with the signature of the EU-Korea FTA in 2010, when the EU's labour rights provisions were packaged together with rules concerning environmental protection in a 'Trade and Sustainable Development' (TSD) chapter. ${ }^{20}$ This chapter has since become a standard part of the agreements the EU negotiates with its trading partners. ${ }^{21}$

While there is some variation between the provisions in the different agreements as a result of the outcome of negotiations with individual treaty partners, there are core elements to be found in TSD chapters across all recent EU trade deals. In each agreement, the same approach can be identified as to the context in which labour standards are invoked, the substantive labour standards relied upon, the institutional structures created, and the manner in which complaints are handled.

Setting the context, each agreement recognises the importance of labour standards if trade agreements are to promote sustainable development and globalisation is to create widespread social benefits. ${ }^{22}$ In terms of substantive standards, all the agreements involve the parties making commitments in relation to the ILO's Core Labour Standards, i.e. freedom of association and the effective recognition of collective bargaining, the elimination of forced and compulsory labour, the abolition of child labour, and the elimination of discrimination in respect of employment and occupation. Commitments to substantive standards are accompanied by a range of procedural commitments, including on dialogue and co-operation (via the institutional structures mentioned below); transparency when introducing new labour standard measures domestically; monitoring and review of how the agreement affects sustainability; a commitment to uphold levels of domestic protection

20 Free Trade Agreement Between the European Union and Its Member States, of the One Part, and the Republic of Korea, of the Other Part [2011] OJ L127/6.

21 As of December 2018, such chapters feature in finalised agreements with Canada, Colombia/Peru, Central America, Georgia, Moldova, Singapore, the Southern African Development Community, Ukraine, and Vietnam. Exceptions include the Economic Partnership Agreements with East African Community, with Economic Community of West African States, and with Central Africa, which are notable because they were negotiated over the same years as some of other agreements that do contain labour provisions.

22 For example, Council Decision (2014/492/EU) of 16 June 2014 on the signing, on behalf of the European Union, and provisional application of the Association Agreement Between the European Union and the European Atomic Energy Community and Their Member States, of the One Part, and the Republic of Moldova, of the Other Part [2014] OJ L26o/1, Article 365 of the Trade and Sustainability chapter states that the EU and Moldova 'reaffirm their commitment to promote the development of international trade in a way that is conducive to full and productive employment and decent work for all.' 
in relation to labour rights; a commitment not to use labour standards for the purposes of disguised protectionism and to uphold existing domestic labour laws; and a commitment not to weaken or waive laws to encourage trade or investment. ${ }^{23}$

In terms of institutional oversight, all the chapters include the establishment of a joint committee composed of official representatives from the two parties who will oversee the implementation of the chapter. This is accompanied by a civil society mechanism (CSM) bringing together representatives of business, trade unions, NGOs, and (occasionally) academia in so-called Domestic Advisory Groups, and facilitating international dialogue between these parties through a civil society forum. The dispute settlement process applicable to the other chapters of the agreement, allowing a complaint that could result in the suspension of trade preferences vis-à-vis the other party, is not available (i.e. there is no sanctioning power). Rather, complaints are handled by a panel of experts whose role is simply to report its findings in a manner consistent with the institutional framework established under each agreement. ${ }^{24}$

EU policymakers have placed significant emphasis on these TSD chapters and the labour standards contained within them. The Directorate-General for Trade, in its strategic plan for 2016-2020, has recognised that trade policy has come under increased public and civil society scrutiny, and that 'strong provisions [in FTAs] to promote the respect of labour rights' are key to the response. ${ }^{25}$ Labour provisions are presented as crucial to ensure trade is 'for all' and 'not just about economics, but about values'. ${ }^{26}$ As such, the EU's approach is often characterised by, inter alia, the European Commission as 'universalist' in character insofar that its aim is to use labour provisions in trade agreements to gradually improve labour standards worldwide. ${ }^{27}$ Nowhere does the Commission argue that its labour provisions are intended to protect EU industry from 'unfair' competition based on the cheaper costs of labour in countries where workers' rights are exploited once trade agreements have

\footnotetext{
23 For instance EU-Korea FTA, ch 13.

24 ibid. For more detail on the key aspects of this model, see Lorand Bartels, 'Human Rights and Sustainable Development Obligations in EU Free Trade Agreements' (2013) 40 LIEI 297.

25 Commission, DG Trade, 'Strategic Plan 2016-2020' (2016) <https://ec.europa.eu/info/ publications/strategic-plan-2016-2020-trade_en $>$ accessed 19 July 2019.

26 Commission, Trade for All: Towards a More Responsible Trade and Investment Policy (EU 2015); Cecilia Malmström, 'Responsible Supply Chains: What's the EU Doing?' (EU and Global Value Chains conference, Amsterdam, Netherlands, 7 December 2015). 
come into force. ${ }^{28}$ This is not to say that the latter rationale should be outright discounted. Many lobbies and citizens across Europe do appear concerned about the effects of opening up markets without safeguarding fundamental workers' rights in trade partners. ${ }^{29}$ Ultimately, if one is to judge their impact, it is more valuable to understand how labour provisions have worked in practice, rather than to rely on statements about their intended goals.

There is now a growing literature about the effects of EU labour provisions on the protection and promotion of labour standards in trade partner countries. A number of studies have examined the effectiveness of the EU's TSD chapters based on extensive interviews and analysis of documentary evidence, in trading partners as well as the EU. ${ }^{30}$ These studies have identified a series of important limitations and failings in the current operation of the EU's TSD chapters.

Key failings include the fact that relevant officials in both the EU and in trade partners lack detailed knowledge of labour issues and/or do not see them as a priority issue..$^{31}$ As a result, insufficient attention has been paid to the complex and varied labour issues encountered in the EU's diverse trading partners, and to how TSD chapters can effectively engage with them. ${ }^{32}$ Simultaneously, despite the formally reciprocal nature of the obligations in labour chapters, labour issues within the EU are barely considered. ${ }^{33}$ Studies also find that CSMs within FTAs are undermined by serious operational failings, including

28 This rationale is not found in any of the policy documents that spells out EU policy on trade and labour.

29 See eg Marion Jansen, Ralf Peters and José Manuel Salazar-Xirinachs (eds), Trade and Employment: From Myths to Facts (ILO 2011) 2; The Alternative Trade Mandate Alliance, 'Trade: Time for a New Vision' (2014) <www.s2bnetwork.org/wp-content/uploads/2013/ 11/trade-time_for_a_new_vision1.pdf > accessed 19 July 2019 .

30 This literature is reviewed in James Harrison and others, 'Labour Standards Provisions in EU Free Trade Agreements: Reflections on the European Commission's Reform Agenda' (2018) WTR 1.

31 See eg Axel Marx, Brecht Lein and Nicolas Brando, 'The Protection of Labour Rights in Trade Agreements: The Case of the EU-Colombia Agreement' (2016) 5o JWT 587; Jan Orbie and Lore Van den Putte, 'Labour Rights in Peru and the EU Trade Agreement: Compliance with the Commitments Under the Sustainable Development Chapter' (2016) OFSE Working Paper $58<$ <ww.econstor.eu/handle/10419/145974> accessed 19 July 2019; James Harrison and others, 'Governing Labour Standards Through Free Trade Agreements: Limits of the European Union's Trade and Sustainable Development Chapters' (2018) 57 J Common Mkt Stud 26o.

32 Harrison and others (n 30$)$.

33 ibid 12. Harrison and colleagues question whether the EU's model is really a two-way process of dialogue or whether it is rather is a form of 'sophisticated unilateralism'. While labour violations may be more serious in many of the EU's trading partners, there are also many serious problems within the $\mathrm{EU}$, eg in relation to the rights of migrant workers. 
a lack of resources and insufficient time in meetings to address labour issues. ${ }^{34}$ The overall purpose and function of CSMs are also unclear. ${ }^{35}$ Cooperative activities, which are envisaged as central to the ethos of the TSD chapters, have not been systematically implemented ${ }^{36}$ When conflicts do arise over whether obligations have been fulfilled, the 'soft' dispute resolution provisions are inadequate to resolve such situations. The absence of a threat of meaningful sanctions translates into a limited deterrent effect. Furthermore, even where clear breaches have occurred, the European Commission has been reluctant to invoke the dispute resolution option. ${ }^{37}$ Finally, the monitoring of the 'sustainability' impact of the agreements themselves, including how the obligations across the agreements have had positive and negative impacts on the lives of workers, has not been properly operationalised. ${ }^{38}$

The breadth of these failings justifies the conclusion that TSD chapters, as currently constituted, seem incapable of having any significant effect. ${ }^{39}$ Such a view is not found only within academia. Many trade unions, non-governmental organisations, and members of the European Parliament have likewise been heavily critical of TSD chapters. ${ }^{40}$ This assessment of the functioning of the TSD chapters led the European Commission to embark upon a reform agenda (see Section 5). But what is clear is that the EU has neither relied on its significant 'market power' to push for labour provisions that have significant impacts within trade partners, nor has it successfully used persuasion to export the norms and principles embodied within the core ILO conventions it purports to

34 See eg Lore Van den Putte, 'Involving Civil Society in Social Clauses and the Decent Work Agenda' (2015) 6 Glob Lab J 221; Marx and others (n 31); Orbie and Van Den Putte (n 31); Harrison and others (n 31).

35 Harrison and others ( $\mathrm{n} 30)$.

36 ibid; Franz Ebert, 'Labour Provisions in EU Trade Agreements' (2016) 155 Intl Lab Rev 407.

37 See eg Angie N Tran, Jennifer Bair and Marion Werner, 'Forcing Change from the Outside? The Role of Trade-Labour Linkages in Transforming Vietnam's Labour Regime' (2017) 21 Comp \& Change 397; Marx and others (n 31); Ebert (n 36); Harrison and others (n 31$)$.

$38 \quad$ Marx and others (n 31); Harrison and others (n 31$)$.

39 Harrison and others (n 31$)$.

40 The extent of criticism of TSD chapters can best be seen by many of the responses received by the Commission to its unofficial consultations, see Letter from Klaus Müller, Executive Director of the Federation of German Consumer Organisations, to Sandra Gallina, Deputy Director-General, DG Trade (9 November 2017). See also the European Commission's own characterisation of the issue at Commission, 'Trade and Sustainable Development (TSD) Chapters in EU Free Trade Agreements (FTAs)' (2017) Non-Paper of the Commission Services, $2<\mathrm{http} / /$ trade.ec.europa.eu/doclib/docs/2017/july/tradoc _155686.pdf> accessed 19 July 2019. 
promote. ${ }^{41}$ However, the limitations of the EU model have been disseminated through its trade agreements to other countries, some of whom have then copied it, with some variation, in their trade agreements with third parties. ${ }^{42}$

The origins of the US approach are found in the 1994 North American Free Trade Agreement (NAFTA) between the United States, Canada and Mexico. ${ }^{43}$ NAFTA was the first US trade agreement to include labour provisions, albeit in a side agreement. ${ }^{44}$ Since then, every FTA signed by the United States has included labour provisions - now totalling agreements involving 20 countries. ${ }^{45}$ Labour provisions have also become more central to US FTAs. From the 2004 FTAs with Chile and Singapore onward, labour provisions have been set out in a dedicated 'Labour Chapter'.

The US labour chapters share similar features across agreements with different trade partners. ${ }^{46}$ However, the common formulation approach is somewhat weaker in the US model due to the fact that changes in political administrations have led to changes in the approach to the labour provisions within FTAs. Still, an evolving 'pre-Trump' approach, as developed through the Bush and Obama administrations, can be identified. There is significant overlap with the EU approach. ${ }^{47}$ Both create commitments in relation to the ILO's

41 On the concept of EU market power, see Chad Damro, 'Market Power Europe' (2012) 19 JEPP 682. In relation to the normative power of the EU, see Ian Manners, 'The Social Dimension of EU Trade Policies: Reflections from a Normative Power Perspective' (2009) 14 EFA Rev 785 .

42 See International Labour Organisation, Social Dimensions of Free Trade Agreements (IILS 2013).

43 The North American Free Trade Agreement (signed 17 December 1992, entered into force 1 January 1994) 32 ILM 289, 605.

44 The side agreement was the North American Agreement on Labor Cooperation (opened for signature 8 September 1993, entered into force 1 January 1994) 32 ILM 1499 (NAALC). NAALC sets out a series of 'Labour Principles' which all three parties to NAFTA commit to promote.

45 These are with Australia, Bahrain, CAFTA-DR (Costa Rica, Dominican Republic, El Salvador, Guatemala, Honduras, Nicaragua), Chile, Colombia, Israel, Jordan, Republic of Korea, NAFTA (Canada, Mexico), Morocco, Oman, Panama, Peru, and Singapore.

46 For a much more detailed elaboration of this approach, see Jeffrey Vogt, "The Evolution of Labor Rights and Trade - A Transatlantic Comparison and Lessons for the Transatlantic Trade and Investment Partnership' (2015) 18 JIEL 827.

47 Ferdi De Ville, Jan Orbie and Lore Van den Putte, 'TTIP and Labour Standards' (2016) European Parliament, Committee on Employment and Social Affairs, IP/A/EMPL/2015-07. 
core labour standards ${ }^{48}$ seek to prevent a weakening of labour law to attract investment, seek to involve civil society in the negotiation and monitoring of provisions, ${ }^{49}$ involve cooperative activity aimed at strengthening labour rights between the parties, and establish dispute settlement procedures involving inter-governmental dialogue and panels of adjudicators. ${ }^{50}$

But there are also significant differences. Unlike the EU, there has been no effort by the United States to package labour provisions as part of a broader approach to tackle the 'sustainable development' dimensions of trade relationships. Labour and environmental issues are addressed in separate chapters. The implications of this difference are most clearly seen in the monitoring and reporting processes created by the two agreements. Whereas the EU model contains an obligation to monitor and review the sustainability (including labour) impacts of the agreement itself, the US model concentrates on reporting in relation to relevant labour issues within the parties to the agreement. The US model thus focuses on reaching out to address labour issues in the domestic systems of its trade partners. The EU model, on the other hand, centres - at least in theory - on reaching into the trade agreement to ascertain how the new trading relationship itself will affect conditions for workers, together with broader social and environmental impacts, once the trade agreement comes into force.

In terms of substantive standards, the US approach includes commitments to respect 'internationally recognised labor rights', and reference is made to the ILO Declaration on Fundamental Principles and Rights at Work (1998). But there is neither a commitment from parties to the agreement to sign and ratify the ILO's core conventions, nor to effectively implement them once in force (The United States itself has only ratified two of the eight fundamental conventions). ${ }^{51}$ Rather, the United States has prioritised efforts to improve national legal processes for the enforcement of labour rights. ${ }^{52}$

48 Although there is an important debate about the legal effects of referencing only the ILO Declaration, as opposed to directly referencing the ILO Conventions in the text of trade agreements. Jordi Agustí-Panareda, Franz C Ebert and Desirée LeClercq, 'Labour Provisions in Free Trade Agreements: Fostering Their Consistency with the ILO Standards System' (2014) ILO Background Paper < www.ilo.org/inst/projects/labour-standards-in-trade-and -investment-arrangements/WCMS_237940/lang-en/index.htm> accessed 19 July 2019.

The US approach involves a Labor Affairs Council comprised of high-level representatives of the parties, a Labor Cooperation Mechanism to promote joint activities by State officials and encourage each party to establish a National Labor Advisory Committee comprised of civil society actors to give advice on implementation.

$50 \quad$ De Ville, Orbie and Van den Putte (n 47) provide a comparative overview.

$5^{1}$ On the debate about the legal effects of referencing only the ILO Declaration, as opposed to directly referencing the ILO Conventions in the text of trade agreements, see Agustí-Panareda, Ebert and LeClercq (n 48).

De Ville, Orbie and Van den Putte (n 47). 
The United States has a different model of enforcement of its labour provisions vis-à-vis its trading partners. While the resolution of disputes between State Parties to FTAs start with similar consultation processes as undertaken through the EU model, complaints that cannot be resolved through consultations are subject to the same dispute settlement process as those arising out of commercial chapters of the trade agreement, although the procedures and penalties for non-compliance can differ. For instance, in the United States-Dominican Republic-Central America FTA (US-DR-CAFTA), there is a limit of USD 15 million on the compensation that can be imposed for nonimplementation of labour laws, whereas for non-implementation of other obligations in the agreement (e.g. intellectual property), the penalty that can be imposed is unrestricted. ${ }^{53}$ Despite such limits on sanctions available, this model differs greatly from the soft advisory role of the complaints mechanism under the EU model.

As in the EU, labour provisions have played an important role in legitimating overall US trade policy, and became significant pre-conditions for trade agreements to gain the necessary political support domestically. ${ }^{54}$ Also, similar to EU labour provisions, US provisions have been a means of demonstrating the universalist concern about the importance of protecting workers' rights globally. ${ }^{55}$ Alongside this, and contrary to the EU, US administrations have explicitly stated that labour provisions are included in trade agreements to address fears of competition from abroad. They have been seen as important in demonstrating to key US constituencies that the US administration is keeping a 'level playing field' on labour rights between the United States and its trading partners. ${ }^{56}$ As explored in Section 5 below, this latter rationale has become dominant under the Trump administration.

To a limited degree, academic analysis has identified more significant effects from the US approach. Compared to the EU, the United States has taken stronger action with regard to pushing for labour law reform before signing trade agreements - using so-called pre-ratification conditionality. There is evidence, for instance, that pressure from US authorities to take action resulted in legislative changes to improve labour law protections and/or led to other actions (e.g. the hiring of more labour inspectors) before FTAs with Bahrain, Columbia,

53 A critique of CAFTA's dispute settlement provisions in relation to labour, and how these are handled compared to those in commercial disputes, can be found in Vogt (n 46) 832 .

54 Holger Janusch, 'Labor Standards in US Trade Politics' (2015) 49 JWT 1047.

55 Office of the US Trade Representative, 'Labor' < https://ustr.gov/issue-areas/labor > accessed 19 July 2019 .

56 Office of the US Trade Representative, 'Trade Policy: A Level Playing Field for American Workers' (July 2009) <https://ustr.gov/about-us/policy-offices/press-office/fact-sheets/ 2009/july/trade-policy-level-playing-field-american-workers> accessed 19 July 2019. 
Morocco, Oman, and Panama came into force. ${ }^{57}$ But such actions do not necessarily mean that the most serious labour issues were effectively addressed prior to ratification. For instance, evaluations of the labour reforms actually carried out in Peru and Colombia found that serious deficiencies remained unaddressed, both in terms of the relevant laws and their implementation. ${ }^{58}$

Once an agreement has entered into force, it is the US agreements' stronger form of dispute settlement procedures that has been widely seen as important to the United States' ability to induce its trade partners to ensure de jure and de facto protection of labour rights. ${ }^{59}$ First, the threat of meaningful sanctions creates a more powerful incentive towards action in the dialogue and cooperative activity which occurs through the Labour Chapters. However, such opportunities have not always been taken by US officials for whom engagement with labour commitments has not generally been a priority. ${ }^{60}$ Second, as a result of the more open US complaints process, complaints have been brought by trade unions and labour NGOs from the United States and its trading partners. These are initially investigated by the US Department of Labor. Such complaints have been investigated in seven countries to date, resulting in various follow-ups, including government-level action plans. ${ }^{61}$ However, action plans are not always enacted in practice, and there is scepticism about whether interactions between the US Government and the governments in trading partners has actually led to better conditions for workers at the level of individual enterprises operating within the territory of the United States' trading partners. ${ }^{62}$

57 JF Hornbeck, 'Free Trade Agreements: US Promotion and Oversight of Latin American Implementation' (2009) Inter-American Development Bank PB-Io2 <https://publications .iadb.org/en/publication/free-trade-agreements-us-promotion-and-oversight-latin -american-implementation> accessed 19 July 2019; Vogt (n 46).

$5^{8}$ Vogt (n 46) 837. As in the EU, the formal reciprocity of these commitments, in practice, only works one way - there is never pressure on the US in relation to labour law or its implementation.

59 Tran, Bair and Werner ( $\mathrm{n} 37)$.

6o See US Government Accountability Office, Report to the Chairman, Committee on Finance, US Senate, 'Four Free Trade Agreements GAO Reviewed Have Resulted in Commercial Benefits, but Challenges on Labor and Environment Remain' (July 2009) GAO-09-439, 52. The report states ' $[\mathrm{w}]$ ith respect to the labor obligations in these FTAs, the responsible US agencies have made little or no effort, or a belated effort, to identify labor compliance concerns after FTA enactment, and engagement with these partners on labor issues has been a low priority most of the time.'

61 These are Bahrain, Colombia, Dominican Republic, Guatemala, Honduras, Mexico, and Peru. See US Department of Labor, Bureau of International Labor Affairs, 'Submissions Under Labor Provisions of Free Trade Agreements' <www.dol.gov/agencies/ilab/our -work/trade/fta-submissions> accessed 19 July 2019.

$62 \quad$ Vogt $(\mathrm{n} 46) 858$. 
Only one case has so far been taken to arbitration under the US-DR-CAFTA, which concerns the failure of Guatemala to effectively enforce its own labour law. ${ }^{63}$ Although the case was formally launched by the United States in 2010, the dispute settlement panel only reported its findings in June 2017. The Panel found in favour of Guatemala. While the United States was able to prove that, at eight different worksites, Guatemala had failed to enforce its labour law, they were unable to demonstrate that 'these instances constitute a course of action or inaction that was in a manner affecting trade. ${ }^{64}$ The Panel identified the legal test through which to determine whether action or inaction affected trade as: 'a failure to effectively enforce a Party's labor laws through a sustained or recurring course of action or inaction [that] confers some competitive advantage on an employer or employers engaged in trade between the Parties. ${ }^{65}$ Applying that test to the facts of the case, the Panel found that, collectively, Guatemala's law enforcement failures demonstrated a sustained or recurring course of action, but not conduct in a manner affecting trade. When the one law enforcement failure that was found to be affecting trade was considered separately, the Panel did not find a sustained or recurring course of action and, as such, did not find a breach of obligations. ${ }^{66}$

The approach of the Panel has been viewed by academic commentators as creating significant difficulties in terms of bringing successful cases in the future. ${ }^{67}$ It has been argued that, to demand 'recurring or sustained action or inaction' for each workplace that is the subject of the complaint, rather than across an entire industry or sector, is excessively onerous. ${ }^{68}$ This decision has also prompted a broader political crisis of confidence in the US model, with senior politicians and trade unions representatives contending that the outcome of the case proved that the labour provisions were unworkable. ${ }^{69}$

63 The US Government formally requested cooperative labour consultations with Bahrain, but no case has yet been filed. See text to $\mathrm{n} 6$.

64 In the Matter of Guatemala - Issues Relating to the Obligations Under Article 16.2.1 (a) of the CAFTA-DR, Arbitral Panel Established Pursuant to Chapter Twenty, Final Report of the Panel (14 June 2017).

65 ibid para 190.

66 ibid paras 590-594.

67 Phillip Paiement, 'Leveraging Trade Agreements for Labor Law Enforcement: Drawing Lessons from the US-Guatemala CAFTA Dispute' (2017) 49 Geo J Intl L 675; Tequila Brooks, 'US-Guatemala Arbitration Panel Clarifies Effective Enforcement Under Labor Provisions of Free Trade Agreement' (2018) 4 Intl Lab Rts Case L 45.

68 Paiement (n 67) 690.

69 See eg Press Release of Richard Neal and Bill Pascrell Jr, 'Statements on Guatemala Labor Report' (26 June 2017) <https://neal.house.gov/media-center/press-releases/neal -pascrell-statements-guatemala-labor-report> accessed 19 July 2019; Celeste Drake, 'US 
Arguably, however, greater problems exist in terms of getting cases to dispute settlement in the first place. Out of almost 50 complaints made so far under US FTAs (the vast majority of which relate to NAFTA), only the Guatemala case made it to the dispute settlement stage..$^{70}$ Similarly to the situation with regard to EU FTAs, lack of political will on the part of the US administration has been identified as the rationale behind the failure to pursue more cases. ${ }^{71}$ Collectively, these problems have led to the crisis in confidence in US labour provisions becoming analogous to that levelled at the EU's regime. ${ }^{72}$

\section{5}

\section{Reform of the EU and US Models}

The inadequacy of the EU and US models has been widely recognised among proponents of labour provisions on both sides of the Atlantic. These concerns have not gone unaddressed. In both cases, efforts have been made to more effectively address labour issues through trade agreements. Although the reform agendas are motivated by different factors, one can argue that in some ways each suffers from the same deficiencies.

Driven by criticism from trade unions, NGOs, and the European Parliament, the European Commission embarked on a reform process in mid-2017. ${ }^{73}$ This process was not informed by any serious attempt to review the impact of the EU's existing trade agreements on workers and their rights in the EU and trade partner countries, nor to seek to create mechanisms which effectively address those issues. This is unsurprising, given the fact that, as identified above, provisions to monitor the sustainable development - including labour - impact of EU FTAs have not been properly operationalised. Rather, the Commission's review focused narrowly on proposals to strengthen existing mechanisms within TSD chapters. The Commission rejected the idea of stronger dispute settlement, which had been the key demand of many of those

Trade Policy Fails Workers' (AFL-CIO, 26 June 2017) <https://aflcio.org/2017/6/26/us -trade-policy-fails-workers $>$ accessed 19 July 2019.

70 See ILO, 'Social Dimensions FTAs' (n 42) for an overview of many of these cases.

71 Axel Marx, Franz Ebert and Nicolas Hachez, 'Dispute Settlement for Labour Provisions in EU Free Trade Agreements: Rethinking Current Approaches' (2017) 5 Politics and Governance 49, 52. See also Vogt (n 46).

72 Cassandra Waters, 'Labor Rights Protections in Trade Deals Don't Work' (AFL-CIO, 24 October 2017) <https://aflcio.org/2017/10/24/labor-rights-protections-trade-deals-dont -work> accessed 19 July 2019. Such perceptions are also taking root in the academic literature, Araujo B Melo, 'Labour Provisions in EU and US Mega-Regional Trade Agreements: Rhetoric AND Reality' (2018) 67 ICLQ 233.

Commission (n 40). 
calling for reform. ${ }^{74}$ In part, the Commission used the perceived inadequacies of the US model as a rationale for this rejection. ${ }^{75}$ Instead, it promised a series of actions to 'revamp the TSD chapters', including working more closely and communicating better with key stakeholders; identifying, considering, and addressing priorities (i.e. action plans) for each partner country in relation to TSD issues; encouraging early ratification of core international agreements; enabling civil society to play their role in the implementation of TSD commitments more effectively; and increasing the resources that would be available for the implementation of TSD chapters. ${ }^{76}$ Overall, these reforms hinge on using the existing mechanisms of the TSD chapters to undertake 'more assertive enforcement' of key obligations. ${ }^{77}$

While some of these 'revamps' may address some of the problems previously identified with TSD chapters, ${ }^{78}$ key stakeholders - particularly in trade unions and NGOs - believe that serious deficiencies remain unaddressed. ${ }^{79}$ On the one hand it is suggested that an opportunity to reform EU trade policy to put sustainable development, including the situation of workers in the EU and its trading partners, at the heart of EU trade agreements, has not been taken. TSD issues are still 'ghettoised' within single chapters of agreements, rather than seen as cross-cutting issues which are potentially relevant to all aspects of a trade agreement. ${ }^{80}$ On the other hand, there is scepticism that DG Trade, which is in charge of the negotiation and implementation of TSD

74 See responses to the Commission's non-paper on TSD chapters, Letter from Müller to Gallina ( $n$ 40). Most business organisations were opposed to the idea of stronger dispute settlement.

75 European Commission, 'Feedback and Way Forward on Improving the Implementation and Enforcement of Trade and Sustainable Development Chapters in EU Free Trade Agreements' (26 February 2018) Non-Paper of the Commission Services <http://trade .ec.europa.eu/doclib/docs/2018/february/tradoc_156618.pdf> accessed 19 July 2019. As identified in the academic literature, there are a number of models for dispute settlement which could be drawn upon in these reform efforts. So the sole focus on the inadequacies of the US model looks inappropriate. See Axel Marx and others, Dispute Settlement in the Trade and Sustainable Development Chapters of EU Trade Agreements (Leuven Centre for Global Governance Studies 2016).

76 ibid.

77 ibid.

78 For an evaluation of the reform proposals, see Harrison and others (n 30$) 13$.

79 See 'Report of the Roundtable on Human Rights, Labour Rights and Sustainable Development in EU Trade Policy' (25 May 2018) <https://warwick.ac.uk/fac/soc/law/ research/centres/chrp/governance/eutradeandlabour/report_of_roundtable_25.05.18 .docx $>$ accessed 19 July 2019 .

80 Harrison and others (n 30) 20 offer some ideas on how the latter agenda could be achieved. 
chapters, has the political will to prioritise action on labour issues. ${ }^{81}$ It is early days in terms of an evaluation of the changes the reform process has actually given rise to. As this article was being finalised, the Commission announced it had requested formal consultations with the government of South Korea about its lack of implementation of fundamental labour rights. ${ }^{82}$ This suggests that the Commission may now be more willing to utilise the tools at its disposal to pursue a labour rights agenda. However, European labour representatives point out that the situation in Korea is particularly egregious and remain sceptical about the ability of the labour chapter's soft dispute settlement process to produce meaningful results. ${ }^{83}$ Certainly the Commission's overarching narrative around its TSD agenda makes it clear that the EU's approach will continue to be largely defined by processes of soft cooperation and engagement over a range of sustainable development (including labour) issues, focusing on 'universalist' concerns about perceived problems occurring within trade partner countries. ${ }^{84}$

Consideration of issues in relation to workers in recent US trade policy is framed very differently. Central to Trump's successful election campaign was the idea that future trade deals would ensure benefits to US workers. The nationalist rhetoric of the campaign made it clear that violations of labour rights abroad were a concern only to the extent that they provided unfair competition which harmed workers in the United States. Once in power, Trump's adoption of the 'America First' trade policy has been characterised by withdrawal from trade negotiations, and the imposition of tariffs with a view to creating uncertainty and disruption in the global trading system so as 'to bring about new investment in the United States and the return of factories and manufacturing jobs. ${ }^{\prime 85}$ At the same time, the administration has committed to a strategy of 'bilateral trade negotiations to promote American industry, protect American workers, and raise American wages.' ${ }^{86}$

81 See Report of the Roundtable on Human Rights ( $\mathrm{n} 79$ ).

82 'Republic of Korea - compliance with obligations under Chapter 13 of the EU-Korea Free Trade Agreement', Request for Consultations by the European Union' (17 December 2018).

83 European Trade Union Confederation, 'Trade \& Labour Rights: Toothless Deals Need Teeth!' (17 December 2018) <www.etuc.org/en/pressrelease/trade-labour-rights-toothless -deals-need-teeth $>$ accessed 19 July 2019.

84 Commission ( $\mathrm{n} 75)$.

85 Shawn Donnan, 'Trump's Tariff Strategy Sharpens America First Focus' Financial Times (London, 15 June 2018) <www.ft.com/content/e52c9bac-7ob9-11e8-92d3-6c13e5c92914> accessed 19 July 2019 .

86 The White House, Office of the Press Secretary Press Release, 'Presidential Memorandum Regarding Withdrawal of the United States from the Trans-Pacific Partnership Negotiations and Agreement' (23 January 2017) <www.whitehouse.gov/the 
Within this broader policy-framework, the renegotiation of the NAFTA in the form of the draft United States-Mexico-Canada Agreement (USMCA) provides the first opportunity to evaluate what this means for labour provisions. As with the Commission's reform agenda, US reforms are not based on any attempt to analyse the impact of the existing NAFTA agreement on workers' rights. It is therefore again unsurprising that commentators have found that, while the reformed labour chapter 'entails some interesting legal innovations, the opportunity to address the main structural problems of US trade agreements to date in terms of labour rights has largely been missed.' ${ }^{87}$ Most prominent among the reforms, there is a new test to decide what constitutes 'in a manner affecting trade' that lowers the standard to find a breach and could make successful cases more likely. ${ }^{88}$ But the problems of accessing dispute settlement in the first place remain unaddressed. Critics have therefore questioned whether this change will in fact lead to more successful cases being brought. ${ }^{89}$

Unlike the EU reforms, labour provisions in the USMCA have broken free from their 'ghettoisation' in the labour chapter and have found their way into the 'Rules of Origin Chapter'. The latter chapter provides that vehicles produced within the territory of USMCA countries must have a minimum percentage of component parts produced by workers paid a minimum of USD $16 /$ hour in order to qualify for duty-free treatment. ${ }^{90}$ This is the first time that such minimum wage requirements have been used within the technical rules that govern the production of products in an FTA. ${ }^{91}$ At the same time, these provisions are limited in scope, applying only to the automobile sector, and it remains to be seen what their impact will be in practice. Overall, and

-press-office/2017/o1/23/presidential-memorandum-regarding-withdrawal-united-states -trans-pacific > accessed 19 July 2019.

87 Franz Ebert and Pedro A Villarreal, "The Renegotiated "NAFTA": What Is in It for Labor Rights?' (EJIL: Talk!, 11 October 2018) <www.ejiltalk.org/the-renegotiated-nafta-what-is -in-it-for-labor-rights/> accessed 19 July 2019.

88 Agreement Between the United States of America, the United Mexican States, and Canada (adopted 30 September 2018, not entered into force) art 23.5 (USMCA).

$89 \quad$ Ebert and Villareal (n 87).

9o USMCA, ch 4 , Rules of Origin.

91 Ebert and Villareal, (n 87) who also give a more detailed description of how the scheme operates and a critique of its limitations and failings. The US approach both extends the scope of labour provisions beyond core labour standards to wage issues and takes labour issues beyond their traditional home in labour chapters and connects them up with mechanisms for addressing workers' rights in other chapters of the FTA. See Harrison and others (n 30) 20, which raises both strategies as potentially important in the context of universalist approaches to addressing workers' rights issues. 
similarly to their EU counterparts, US reforms are not grounded in a detailed evaluation of the impact of FTAs on workers' lives, and the strengths and deficiencies of previous labour provisions for addressing those issues.

Labour provisions in FTAs have proliferated in recent years. Public rhetoric from politicians and trade officials has suggested that these provisions are vital to ensure that the social dimensions of globalisation are addressed. In the United States, this rhetoric has increasingly been tied to a nationalistic vision focussed on American workers. In the EU, it is couched in universalistic terms, aspiring to advance the interests of workers globally. Whatever the explicit framing, it is vital to scrutinise carefully what effects labour provisions are actually having in reality. New forms of research into the effects of labour provisions in FTAs have helped to reveal their limited effectiveness. Reforms which seek to strengthen labour provisions have only been enacted recently and more time is needed to properly evaluate them. But lack of reflection on past failures, coupled with limited ambition in reform agendas on both sides of the Atlantic, speak against high expectations.

These issues should not come as a surprise to key actors within the trade regime. Academic studies have found that labour provisions have not been a priority of those charged with negotiating and implementing trade policy in either the United States or the EU. They have largely been a sideshow to the main business of implementing liberalisation commitments and commercial regulatory requirements, which are perceived to be where the benefits of trade agreements lie. By focusing attention on the gap between rhetoric and reality in relation to the labour rights agenda, the hope is that policymakers could be pushed to answer critical questions about trade policy. In the United States, this attention should provoke questions about whether reformed labour provisions will contribute to a new vision of trade policy centred on the interests of the American worker, as opposed to the interests of American owned businesses. In the EU, it should raise concerns about whether workers' interests globally are a central policy concern, or a makeweight that creates political buy-in among key constituents for a strong liberalisation and commercial regulatory agenda. Globally, these findings should prompt new forms of reflection about the critical lessons to be learnt from the trade and labour story. The deficiencies of labour provisions, coupled with the strength of provisions that promote the interests of capital, such as investment and intellectual property protections, mean that it is perhaps more illuminating to see the trade and labour story so 
far as more about class struggle than a struggle between the interests of developed and developing countries.

For many in the mainstream trade community of policymakers and scholars, fears about labour standards encouraging disguised protectionism have created an ambivalence about the labour rights agenda. ${ }^{92}$ If rhetoric and reality were more closely aligned, US labour provisions could lead to those fears being realised. But more attention should be directed to the potential of labour provisions inspired by a universalist vision. The diversity of potential approaches speaks to the need for individual scrutiny of the actual impact of particular proposals, alongside other strategies for protecting and promoting the interests of workers in a globalised economy. ${ }^{93}$ Overall, such an agenda should be of widespread interest, given the threats to economic globalisation posed by the current political climate. Even some of the most ardent proponents of trade liberalisation and integration are beginning to recognise the potential problems with mainstream trade policy for vulnerable workers everywhere. For instance, a joint report by the IMF, World Bank and WTO concluded in 2017 that 'adjustment to trade can bring a human and economic downside that is frequently concentrated, sometimes harsh, and has too often become prolonged. ${ }^{94}$ There is an urgent need to tackle these issues. It is time for the academic and trade policy community to pay more focused attention to the policy tools which purport to address them.

92 The academic literature was most prominent on this issue in the early trade-labour linkage debates, see eg Compa and Diamond (n 13). My personal experience in numerous conversations with policymakers and scholars is that the same concerns are still widely prevalent. But the failures of actual labour standards provisions to have significant effects has meant that, in practice, they can be ignored by many in the field.

93 See Harrison and others (n 30) 20 for a synopsis of some potential strategies for better protecting and promoting the rights and interests of workers through FTAs. Such proposals should be considered alongside other forms of support for workers. See eg Dylan Geraets, 'Ensuring Continued Support for the Rules-Based Multilateral Trading System: The Need for a Public-Private Approach' (2018) 21 JIEL 433; Michael J Trebilcock and Sally Wong, 'Trade, Technology, and Transitions: Trampolines or Safety Nets for Displaced Workers?' (2018) 21 JIEL 509.

94 IMF, World Bank and WTO, 'Making Trade an Engine of Growth for All: The Case for Trade and for Policies to Facilitate Adjustment' (2017) < www.imf.org/en/Publications/ Policy-Papers/Issues/2017/04/08/making-trade-an-engine-of-growth-for-all> accessed 19 July 2019. 